\title{
THE EFFECT OF PRESTIGE IN LANGUAGE MAINTENANCE: THE CASE OF CATALAN IN VALENCIA $^{1}$
}

\section{Raquel Casesnoves Ferrer \\ Universitat Pompeu Fabra}

\begin{abstract}
The fact of speaking a language instead of another at a specific moment in a person's life depends on many and diverse factors such as immigration, the language acquired and spoken at home, and what the dominant and official language is. In addition, in situations where it is possible to choose, speaking one language instead of another is not a neutral choice, in that the values associated with languages have a lot to do with that choice. In the Valencian Community, in Spain, two languages officially coexist: Castilian, the official language within the whole Spanish State, and Catalan, the historical language of the territory, which is undergoing a process of revitalization since the beginnings of the 1980s. At that time, Catalan was perceived as a second-rate language, associated with peasantry, with the rural context and uncultured people from the lower social classes. The technique employed to reveal these values or stereotypes, namely the matched-guise technique (Ros 1984), was used again during the 90s (Blas Arroyo 1995, Gómez Molina 1998) for evaluating the effects of the revitalization program. The results of this work showed that Catalan was gaining more and more prestige, i.e., it was increasingly associated with modern people, city life, learning and social progress. An underlying, though never proved, assumption was that the remarkable improvement in the image of Catalan would be reflected in its use, which would also be more frequent and more widespread. At the beginning of the new millennium the matched-guise technique was applied again, with one new twist: to assess the real extent of prestige associated with speaking Catalan (Casesnoves and Sankoff 2003). Ten years later that study was replicated in order to observe the evolution of linguistic attitudes as well as the progress of the linguistic revitaliza-
\end{abstract}

1 This research was supported by a Ramón y Cajal program of the Spanish Ministry of Science and Technology. Thanks are due to David Sankoff (University of Ottawa) for your constant support and to Jens Normann Jørgensen for your observations. I would also like to thank the students, teachers, and school administrators in Valencia who participated in the experiment. 
tion process. In this presentation, we compare the two data sets to evaluate the effects of linguistic attitudes on the use of Catalan. Has Catalan gained prestige throughout the years? If so, does it have an influence on language use or, on the contrary, are there any other factors such as identity that play a more important role in influencing the choice of speaking Catalan?

Keywords: language contact, linguistic attitudes, linguistic revitalization, matched-guise, Catalan, Valencian, Castilian

\section{Introduction}

The fact of speaking a language or another at a specific moment in a person's life depends on many and diverse factors such as immigration, the language acquired and spoken at home, and what the dominant or official language is. In addition, in situations where it is possible to choose, speaking one language instead of another is not a neutral choice, in that the values associated with languages have a lot to do with that choice.

The studies on linguistic attitudes apply the matched-guise technique (Lambert, Hodgson, Gardner and Fillenbaum 1960) to reveal values that could explain and predict a speaker's behaviour. In Valencia, where Castilian (the official language within the whole of Spain) and Catalan (the historical language of the territory) coexist, this technique has been used several times since the beginnings of the 1980s (Blas Arroyo 1995, Casesnoves 2001, Gómez Molina 1998, Ros 1984). As a matter of fact, it is during those years, specifically in 1983, and after 40 years of the Francoist dictatorship (1939-1975) and imposition of Castilian, that a process of revitalization or "linguistic normalization" (Use and Teaching of Valencian Act) was begun with the objective of bringing Catalan to the level of Castilian in order to reverse the process of Castilianization (or Catalan shift to Castilian). Implicitly, it is supposed that having the same legal status (official status) and level of use in administrative and official context could foster a similar use in non-institutional contexts. On the other hand, the studies on linguistic attitudes showed that Catalan was gaining more and more prestige, i.e. it was associated with positive values such as social progress, modern people, urban life, etc. The underlying assumption of this kind of works is that the improvement in the image of 
Catalan will be reflected in its use. However, this premise has never been proved and it would be possible that the prestige of Catalan was independent from the number of people who speak it. Precisely, the study by Casesnoves and Sankoff (2003) was undertaken to assess the real extent of prestige associated with speaking Catalan. They showed that prestige, at least as it is operationalized in the attitudes literature of Valencia, had not a significant effect on language choice.

This article, based on the data from the work by these authors (collected in 1998) and also on that from the new study carried out in 2008, has a double objective: first, to observe the evolution of linguistic attitudes and the progress of the linguistic revitalization process and, second, to verify if Catalan has gained prestige throughout these 10 years (between 1998 and 2008) and assess the influence of that prestige on the choice of speaking Catalan.

\section{The present situation of Catalan in Valencia}

Nowadays, the number of people able to speak Catalan rises up to 9.200.000 (data based on the surveys carried out between 2003 and 2006 in all Catalan-speaking territories, Generalitat de Catalunya http://www.20gencat.cat). It is the official language in Catalonia, Valencia, the Balearic Islands and the Principality of Andorra and is also spoken in a part of Aragon (la Franja) and Murcia (el Carxe) in Spain, Roussillon in France and the city of Alguero in Italy.

The present situation of the Catalan spoken in Valencia, traditionally and officially named 'Valencian', is the result of centuries of a gradual economy- and prestige-driven language shift towards Castilian, particularly during Franco's dictatorship, but also the result of a program of linguistic normalization undertaken 25 years ago. The data for studying the evolution of the knowledge of Valencian comes from the surveys carried out in different moments along these years: in 1985, at the beginning of the process of linguistic normalization (CCE 1985), when the first measures started to have visible effects and, more recently, in 2005 (AVL 2005), when a radical change in the movement of the population, with the massive arrival of immigrants, and what seems to be a paralyzation of the normalization program by the regional government, places the population oral knowledge of Valencian at levels that are similar to, or even lower than those of the eighties. 
As can be observed in Figure 1, three quarters of the Valencian population understands Valencian but only half of it is able to speak this language.

The level of oral competence is lower now, after 20 years of revitalization, than in the mid-eighties. On the other hand, the ability to read and write Valencian has increased by 20 percent, what can be explained by the introduction of Valencian into the educational system.

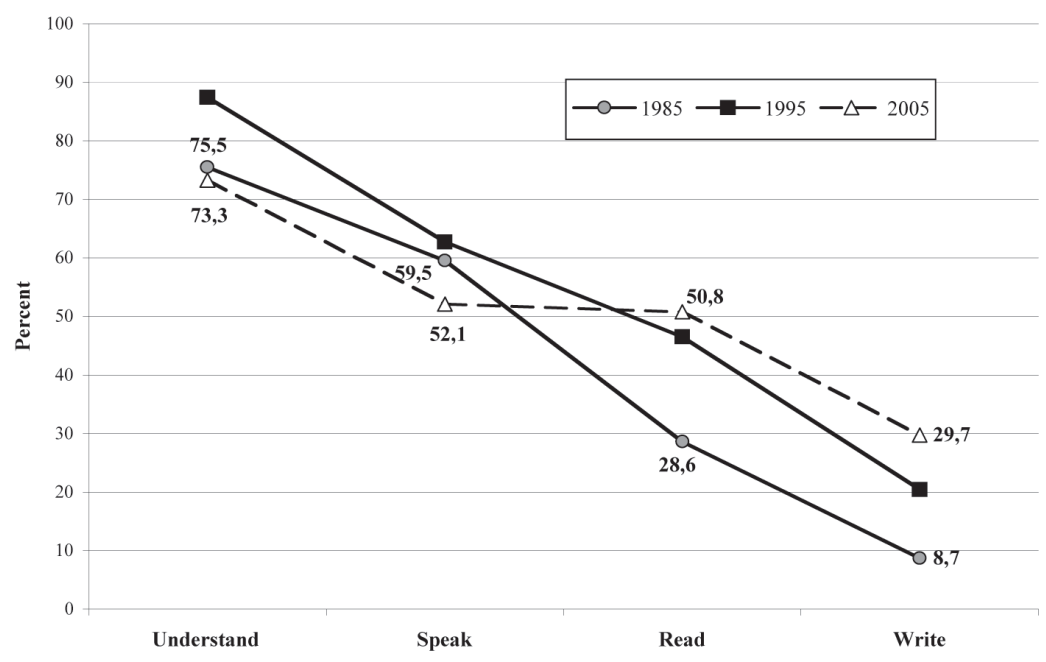

Figure 1. Evolution of the degree of the ability to understand, speak, read and write Valencian in Valencia.

The surveys also reported data about the level of usage of Valencian and Castilian in various contexts, but only for the residents of Valencian-speaking regions ${ }^{2}$. Table 1 shows self-reports of the use of Valencian (always or usually). During the period between 1989 and 1995 there was a general increase in the use of Valencian (except

2 At present we can distinguish two linguistic zones in Valencia: one which is historically Castilian-speaking (comprising the most inner regions on the border with Aragon), and the Valencian speaking one, located mainly along the coast. This division was the result of a historical separation originated with the conquest by the Catalan-Aragon confederation in the 13th century, and has been reinforced by the inclusion of new Castilian-speaking territories in the Castilian-speaking zone. 
in the category "with friends", which remained the same), oscillating between $5 \%$ and $1.5 \%$. On the contrary, the data from the last decade, between 1995 and 2005, reported a sharp decrease in the use of Valencian (between almost 13\% "at home" and 2.5\% "in the street"), which only differs; i.e. is higher, in the supermarket category.

Table 1. Evolution of rate of use of Valencian in various contexts in Valencia.

\begin{tabular}{lccc}
\hline Contexts & $1989^{*}$ & 1995 & 2005 \\
\cline { 2 - 4 } At home & 44.2 & 49.2 & 36.5 \\
With friends & 41.0 & 39.9 & 32.8 \\
In shops & 38.2 & 42.1 & 32.2 \\
In the supermarket & 24.9 & 26.5 & 28.2 \\
In the street & No data & 26.6 & 24.2 \\
\hline
\end{tabular}

* The 1989 survey, which was, as the 1995, carried out by the Cultural Council of the Generalitat Valenciana did not report data about use.

The data for the city of Valencia, the capital of Valencia (where we carried out the study), came from two surveys performed in 1993 and 2006 by the same institution (SIES, data available online http://www.edu.gva.es/polin/es/sies/sies_fonum.htm).

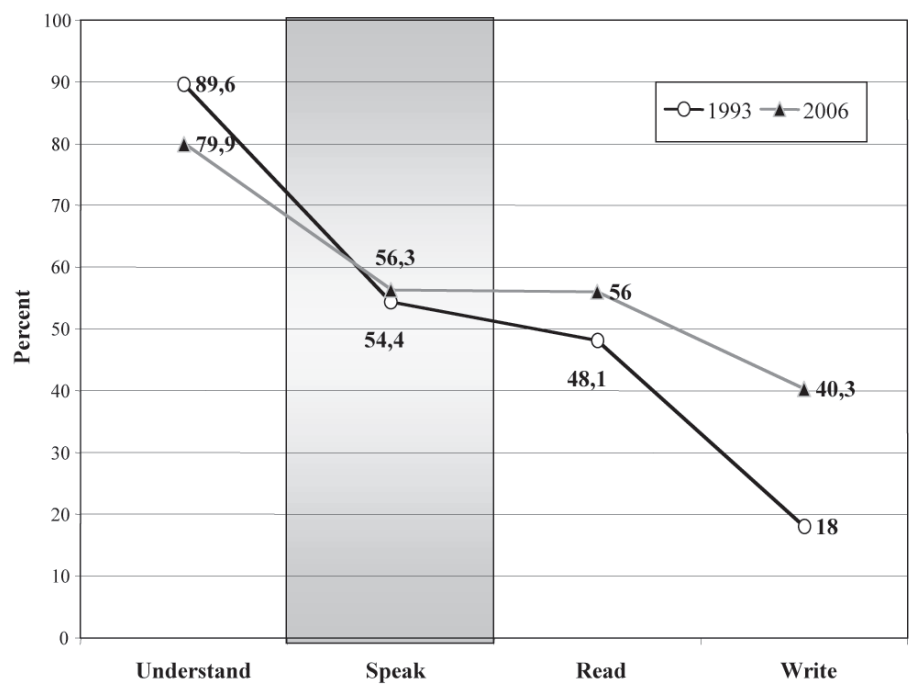




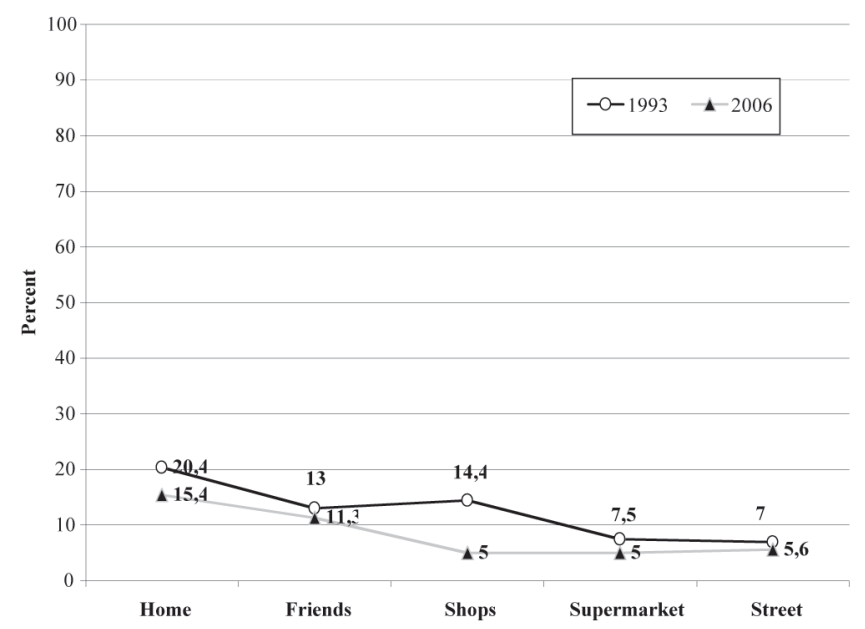

Figure 2. Evolution of the rate of knowledge and use of Valencian in the city of Valencia: 1993 and 2006.

The degree of knowledge of Valencian is slightly higher in the city of Valencia than in the whole of the territory (i.e. Valencia Community), but that is not the case for the rate of use, which results much higher in Valencia (almost 30\%) than in the capital city (between $15 \%$ and $5 \%$ ). Instead, the evolution follows the same tendency at both levels (i.e. Valencian Community and the capital, the city of Valencia): a decrease in the knowledge of oral Valencian and an increase in the ability to read and write it. The use of Valencian also decreases, especially in the shops and at home.

To sum up, in the last decade, the decrease in the knowledge of oral Valencian goes hand in hand with the loss of Valencia speakers, especially in the family context. These results do not correspond or, at least, would not be the expected ones if we take into account that the normalization program is still in force. The external factors mentioned before, the political and demographic ones, could help explain these results, which do not foresee any revitalization but rather an erosion of Valencian. 


\section{Methodology}

We replied the study by Casesnoves and Sankoff (2003), from now on the 1993 study, using the same experimental design, including a variant of the matched-guise technique and a written sociolinguistic questionnaire; the study was carried out in the same places, three secondary schools of the city of Valencia and we applied the same statistical analysis.

\subsection{Experimental design}

The matched-guise technique consists of listening to a series of recordings or speech samples representative of different accents, styles or languages under study, and filling in a reaction test where respondents (or 'judges') evaluate the way in which several psychosocial traits are associated to the speakers they are listening to (as sense of humor, intelligence, etc.) The genius of this technique is that in fact there is only one speaker, so, instead of assessing the personality of individual speakers, in fact they are passing judgment on a series of symbolic and socioeconomic factors associated with these languages; in essence, they are judging the social groups that use those languages.

We used a variant of the matched-guise technique, recording six different speakers, all of them men between 20 and 30 years old, explaining in their mother tongue (Castilian, Valencian or Catalan) how to cook a recipe. Then, the students (respondents) were asked to rate the speakers on personal traits based on a bipolar semantic differential scale and, using seven-point scales, to measure how well they identified themselves with the speaker, etc. As is often done in this type of study, the scales were placed in two groupings: a) status, rated intelligent-stupid (int), educated-uneducated (edu), responsible-irresponsible ( $\mathrm{rsp})$, well-manneredill-mannered (ref), credibility as a university professor (pro), credibility as a boss (boss), and ability to find a job in the European Union (job); b) solidarity, rated trustworthy-untrustworthy (trs), amusing-boring (ams) and evaluator's identification with the speaker (id). 


\subsection{Judges}

The sample of the 1998 study was composed of 167 students, $60.5 \%$ female and $39.5 \%$ male, from two public and one private secondary school. The schools (placed in different districts of the city) were intentionally chosen in order to reflect the diversity of participants according to their origin (from other regions of Spain) and their socioeconomic level. In the 2008 study, apart from the same centers we included another one located in the neighborhood with the highest level of immigrants in order to account for the increase in immigrant population during these years.

A sociolinguistic questionnaire provided information about sociodemographic characteristics, political orientation, feelings of identification with the students' social groups of reference (Valencian, Spanish and Catalan $^{3}$ ) and the degree of use of Valencian and Castilian in different contexts. As regards identity, we constructed two indices by subtracting the score for Valencian identity from the scores for Spanish and Catalan respectively. Thus, the variables 'Catalan' and 'Spanish' identity represent relative degrees of identification with these two groups in comparison with the Valencians.

Concerning language use, the two studies do not follow the same procedure for measuring the degree of use of Valencian and Castilian. In 1998 evaluators were given a questionnaire in which, instead of asking directly what language the students would use in a given situation, they were asked to write what they might SAY in that situation. The responses enabled the establishment of a scale running from the exclusive use of Castilian ('Castilian speakers') to the exclusive use of Valencian ('Valencian speakers'), with the intermediate group ('Bilinguals') in between these two extremes. In 2008 , on the other hand, the questions - which were on the same topics as those used in 1998 - were direct and multiple-

The historic rivalry between the cities of Valencia and Barcelona, something not uncommon among neighbouring cities, was used as a means to create a conflict between Catalonia and Valencia by the central forces that appeared in Madrid during the years of transition from dictatorship to democracy. This brought about a strong anti-Catalan movement, based on the theory that there exists a Catalan 'imperialism' aiming at annexing Valencia. Besides, the supporters of this movement hold the existence of a 'Valencian language' whose origin is different from that of Catalan. 
choice (with a selection of answers that were exclusively in Valencian, exclusively in Castilian and different combinations of the two languages, as well as other languages). Again, a scale was established in which the extremes corresponded to the predominant use of one of the two official languages ('Valencian' and 'Castilian' speakers, respectively), with the intermediate option of indiscriminate use of Valencian and Castilian ('Bilinguals').

\subsection{Speakers}

The students evaluated three standard varieties spoken by three different speakers (Rafa, Toni and Jesus for Castilian, Valencian and Catalan respectively), three non-standard varieties (also spoken by three different speakers) of Valencian spoken in Valencia, one typical of the city $(E d u)$, another from Valencianspeaking villages (Gabriel) and another with a strong Castilian accent (Fidel) and, finally, two non-standard varieties of Castilian (Dani and Abel), one of whom had a strong Valencian accent. Two pairs of samples (one for Valencian and another for Castilian) were recorded from the same speaker (Gabriel-Fidel and Dani$\mathrm{Abel}$ ). The remainder of this article focuses exclusively on the results obtained for the standard varieties.

\subsection{Statistical analysis}

The analysis of the data is based on the causality relations established among all the variables. This way, it is reasonable to postulate that a person's geographic origin helps to determine his or her individual's ideology and behavior, but we cannot say that a person's ideology and behavior affect their place of birth. Thus, in the data analysis it is assumed that sociodemographic factors and political orientation are potentially explanatory of all the other variables.

A series of multiple regression analyses were carried out to determine which variables actually contribute to explain language choice. 


\section{Results}

\subsection{Temporal variation in languages perception}

On a scale from 0 to 100 , figure 3 shows that the standard varieties (Castilian, Valencian and Catalan together) get a higher evaluation than solidarity. Besides, between 1998 and 2008 the evaluation of status decreases while solidarity is maintained (the difference in status being statistically significant). Therefore, we can say that nowadays language prestige is less important than ten years ago.

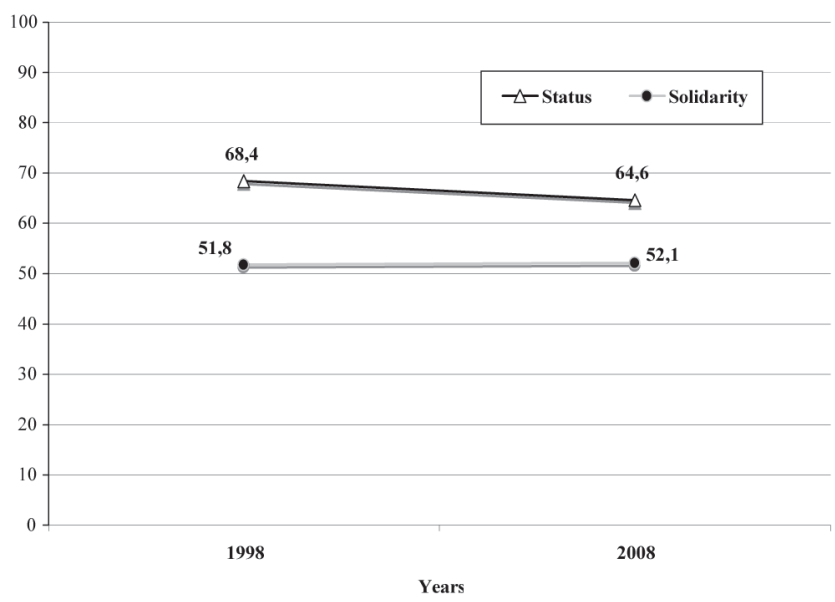

Figure 3. Mean of status and solidarity indices in 1998 and 2008 .

The decrease of prestige affects mainly Castilian, a little less Catalan (the difference of mean between 1998 and 2008 is in both cases significant) but not at all Valencian. On the other hand, Solidarity increases for Castilian at the same time that decreases for Valencian (the differences being also statistically significant) and remains the same for Catalan. 

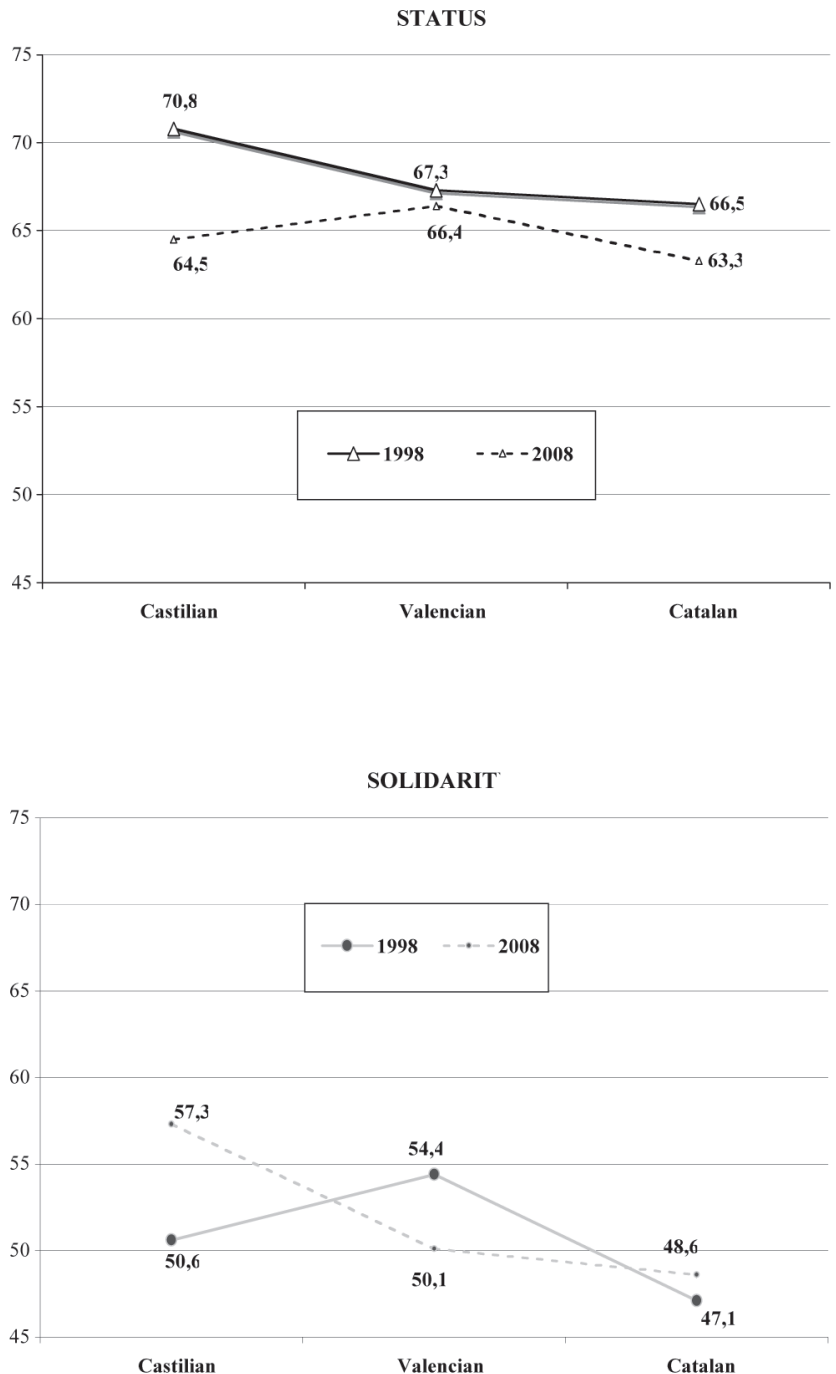

Figure 4. Mean of Castilian, Valencian and Catalan Status and Solidarity in 1998 and 2008.

To sum up, the Valencian students' perception of Castilian is the one which has changed the most over the last ten years: its status is decreasing, but its position as identity language is increasing markedly. 
The prestige of Valencian is not decreasing, but nor is it increasing, which could be expected considering that the language is in the midst of a revitalization process. It is for this same reason that the decline of Valencian as a language of reference and identity is surprising. Finally, the perception of status of Catalan, like Castilian, has decreased. Thus, it could be said that between the late 90s and the first decade of the new millennium, the value of the languages has changed particularly that of those which coexist on a day-to-day basis in Valencia, i.e. Castilian and Valencian.

\subsection{Factors determining the language choice}

Table 2 provides descriptive statistics for the independent variables used in this study. The distribution of students in Table 2 is similar in both studies, except for the decrease of mixed families and undefined students and the increase of students on the right political position.

As discussed above, we carried out a series of regressions based on the notions of causality. Thus, first we verified the effects of sociodemographic variables and political orientation on measures of feelings of identity on the one hand and on linguistic attitudes on the other. Table 3 shows that political orientation, to a lesser degree origin and not at all social class explain a 16 percent of the variation in Catalan identity: right-leaning and immigrant young students identify less with Catalan people than with Valencian people. The same variables explain the 20 percent of the variation in Spanish identity, with rightist and immigrants identifying more with Spaniards than with Valencians. As shown in Table 4, except for the perception of Catalan status (with origin and politics explaining a 5 percent of variation), the linguistic attitudes depend neither on the sociodemographic factors nor on the political orientation. 
Table 2. Ordinal variables used in the 1998 study and 2008 study.

\begin{tabular}{|c|c|c|c|}
\hline Factor & Category & $\begin{array}{c}\text { \% or Mean } \\
1998 \\
(\mathrm{~N}=167) \\
\end{array}$ & $\begin{array}{c}\text { \% or Mean } \\
2008 \\
(N=254) \\
\end{array}$ \\
\hline \multirow{3}{*}{$\begin{array}{l}\text { Origin } \\
\text { (of parents) }^{a}\end{array}$} & Autochthones & 35.5 & 39.4 \\
\hline & Mixed & 36.7 & 25.6 \\
\hline & Immigrants & 27.7 & 29.5 \\
\hline \multirow{3}{*}{$\begin{array}{l}\text { Social class } \\
\text { (by father's } \\
\text { occupation) }\end{array}$} & Upper & 31.5 & 30.7 \\
\hline & Middle & 52.5 & 50.0 \\
\hline & Lower & 17.3 & 19.3 \\
\hline \multirow{4}{*}{ Politics ${ }^{b}$} & Left & 35.9 & 35.4 \\
\hline & Centre & 32.9 & 33.5 \\
\hline & Right & 15.0 & 22.4 \\
\hline & Undefined & 16.2 & 8.7 \\
\hline \multirow[b]{2}{*}{ Identity $^{\mathrm{c}}$} & Catalan & 0.51 & 0.44 \\
\hline & Spanish & 0.71 & 0.74 \\
\hline
\end{tabular}

a The categorization is based on geographical and linguistic criteria: autochthon students are those whose parents were born in the Valencian Country and/or a Catalan speaking zone; mixed if one of the parents was born outside the Valencian Country and/or a Catalan speaking zone and immigrant if both parents come from a Spanish speaking zone of the Spanish State or from abroad.

${ }^{\mathrm{b}}$ As declared on a seven-point scale from extreme left to extreme right. Very few students positioned in one of both extremes and they were included on the left or right respectively.

${ }^{\mathrm{c}}$ It represents the difference between the responses for Catalan (or Spanish) and Valencian.

Table 3. Regression analysis* of identity on sociodemographic factors and politics.

\begin{tabular}{llccc}
\hline $\begin{array}{l}\text { Dependent } \\
\text { variable }\end{array}$ & $\begin{array}{l}\text { Explanatory } \\
\text { variables }\end{array}$ & $\begin{array}{l}\text { Standardized } \\
\text { coefficient (B) }\end{array}$ & sig. & $\mathbf{R}^{\mathbf{2}}$ \\
\hline \multirow{2}{*}{ Catalan identity } & Politics & 0.34 & 0.00 & \multirow{2}{*}{$16 \%$} \\
& Origin & -0.16 & 0.01 & \\
\multirow{2}{*}{ Spanish identity } & Origin & -0.34 & 0.00 & \multirow{2}{*}{$20 \%$} \\
& Politics & -0.31 & 0.00 & \\
\hline
\end{tabular}

* Stepwise regression automatically excludes statistically non-significant explanatory variables. 'Social class' do not appear because it was not chosen for either of the two regressions. 
Table 4. Regression analysis of linguistic attitudes on sociodemographic factors and politics.

\begin{tabular}{llccc}
\hline Dependent variable & $\begin{array}{l}\text { Explanatory } \\
\text { variables }\end{array}$ & $\begin{array}{c}\text { Standardized } \\
\text { coefficient } \\
\text { (B) }\end{array}$ & sig. & $\mathbf{R}^{2}$ \\
\hline Catalan status & Politics & -0.18 & 0.00 & $5 \%$ \\
Castilian status & Origin & -0.15 & 0.03 & \\
Valencian status & (none) & & & \\
Catalan solidarity & (none) & & & \\
Castilian solidarity & (none) & & & \\
Valencian solidarity & (none) & & & \\
\hline
\end{tabular}

Then, we focused on the factors that predict language choice. Taking into account only the sociodemographic and political variables (table 5), it turns out that the variable with most weight is the geographic origin of the students, immigrants being the least likely to speak Valencian. Both, politics and origin together explain only the 8 percent of language variation.

Table 5. Regression analysis of language choice on sociodemographic factors and politics.

\begin{tabular}{llccc}
\hline $\begin{array}{l}\text { Dependent } \\
\text { variable }\end{array}$ & $\begin{array}{l}\text { Explanatory } \\
\text { variables }\end{array}$ & $\begin{array}{c}\text { Standardized } \\
\text { coefficient } \\
\text { (B) }\end{array}$ & sig. & $\mathbf{R}^{\mathbf{2}}$ \\
\hline Choice of & Origin & -0.25 & 0.00 & 8 \\
Valencian & Politics & -0.18 & 0.00 & $\%$ \\
\hline
\end{tabular}

Third, we observed whether the addition of identity to the list of explanatory variables would better predict the behavior of the subjects. Indeed (Table 6), there is an important increase (16 percent) in the proportion of the variation explained, while the effect of political orientation disappears. The Spanish identity has a large effect on the choice of Castilian while the Catalan identity favors the choice of Valencian. 
Table 6. Regression analysis of language choice on sociodemographic factors, politics and identity.

\begin{tabular}{llccc}
\hline $\begin{array}{l}\text { Dependent } \\
\text { variable }\end{array}$ & $\begin{array}{l}\text { Explanatory } \\
\text { variables }\end{array}$ & $\begin{array}{c}\text { Standardized } \\
\text { coefficient } \\
\text { (B) }\end{array}$ & sig. & $\mathbf{R}^{2}$ \\
\hline \multirow{2}{*}{$\begin{array}{l}\text { Shoice of } \\
\text { Valencian }\end{array}$} & $\begin{array}{l}\text { identity } \\
\text { Catalan } \\
\text { identity }\end{array}$ & 0.43 & 0.00 & \\
& Origin & -0.21 & 0.00 & $24 \%$ \\
\hline
\end{tabular}

Finally, we investigated if the use of Valencian would be better predicted including, instead of identity, the six variables measuring linguistic attitudes. Table 7 shows that the explanatory value does not increase but decreases up to 8 percent. Thus, the attitude variables do not contribute to explain the use of Valencian but, instead, diminish the effects of politics and origin.

Table 7. Regression analysis of language choice on sociodemographic factors, politics and attitudes.

\begin{tabular}{llccc}
\hline $\begin{array}{l}\text { Dependent } \\
\text { variable }\end{array}$ & $\begin{array}{l}\text { Explanatory } \\
\text { variables }\end{array}$ & $\begin{array}{c}\text { Standardized } \\
\text { coefficient } \\
(\mathbf{B})\end{array}$ & sig. & \multirow{2}{*}{$\mathbf{R}^{2}$} \\
\cline { 2 - 4 } $\begin{array}{l}\text { Choice of } \\
\text { Valencian }\end{array}$ & Origin & -0.27 & 0.00 & \\
\hline
\end{tabular}

To recapitulate, the indices of identity (based on the feelings of identification with Catalans minus those with Valencians and feelings of identification with Spaniards minus those with Valencians) have more predictive value on language use than any other factor, either politic or demographic, while the perception of prestige of the linguistic varieties has no effect whatsoever. 


\section{Conclusions}

The recent official data shows that the level of knowledge and use of Valencian is similar to or less than that registered in the mid-eighties, the period in which the linguistic revitalization program was set up. The effects of the new linguistic policy, which were positive during the first decade, are now going against what was expected. The change of autonomic government, of a more central inclination since the mid-nineties, together with the change of population movement, marked by the recent arrival of immigrants, could explain the fact that there are fewer Valencian speakers now than 25 years ago.

It is true that Valencian is no longer associated to poorly educated people who lack a high income but rather evaluated as positive as Castilian, which has always been the prestige language. However, the higher or lower status of Valencian in comparison with Castilian has no direct effect on the former being more or less used. In 1998 the official language of the State, i.e. Castilian, was still the language of prestige in Valencia, but that did not account for the fact that Castilian was more used than Valencian (Casesnoves and Sankoff 2003). After ten years, the Valencian language status has remained stable, but that of Castilian has decreased. But neither in this case does our analysis allow us to confirm that this fact is related to language use, and the evolution in the use of Valencian by the population supports this finding, as the number of Castilian speakers has increased. This reveals that the factors that influence and explain language choice are of a different nature and, therefore, have to be sought in other parameters. The hypothesis implicit in the work using matched-guise technique that language status determines language choice is not supported by our study, at least in the case of Valencian.

Considering the variables studied here, it was found that identity tends to be the one which is most related to the motivations behind language choice. The results have shown that the indices of identity (Catalan and Spanish), partly determined by the students' origin and political inclination, explain the $25 \%$ of the use of Valencian. The increase in young right supporters and a higher degree of identification with Spanish people have turned out to be, at least in our study, completely coherent with the rising number of Castilian speakers. 


\section{Address:}

Raquel Casesnoves Ferrer

Institut Universitari de Lingüística Aplicada

C/ Roc Boronat 138

08018 Barcelona

Spain

E-mail: raquel.casesnoves@upf.edu

\section{References}

AVL (Acadèmia Valenciana de la Llengua) (2005) Llibre blanc de l'ús del valencià-I. Enquesta sobre la situació social del valencià. 2004. Valencia: Acadèmia Valenciana de la Llengua.

Blas Arroyo, J.L. (1995) “De nuevo el español y el catalán, juntos y en contraste. Estudio de actitudes lingüísticas”. Sintagma 7, 29-41.

Casesnoves, R. (2001) "Conflit linguistique et conflit politique reflétés dans les attitudes et le comportement linguistique des jeunes lycéens de Valence". Unpublished doctoral thesis, University of Montreal, Montreal, Canada.

Casesnoves, R. and D. Sankoff (2003) Identity as the primary determinant of language choice in Valencia". Journal of Sociolinguistics 7, 1, 50-64.

CCE (Conselleria de Cultura y Educación de la Generalitat Valenciana) (1985) Estudi sociològic sobre la problemàtica sociolingüística a la Comunitat Valenciana. Valencia: Generalitat Valenciana.

CCE (1995) Enquesta sobre l'ús del valencià Maig 1995. Comparació amb 1989 i 1992. Valencia: Generalitat Valenciana.

Generalitat de Catalunya. Electronic statistics. Retrieved October 12, 2009, from http://www20gencat.cat

Gómez Molina, J.A. (1998) “Actitudes lingüísticas en una comunidad bilingüe y multilectal. Área metropolitana de Valencia”. Cuadernos de Filología, Anejo XXVIII. Facultad de Filología. Universitat de València.

Lambert, Wallace E., R. C., Hodgson Gardner, and S. Fillenbaum (1960) "Evaluational reactions to spoken languages". Journal of Abnormal and Social Pyschology 60, 44-51.

Ros, M. (1984) "Speech attitudes to speakers of language varieties in a bilingual situation". International Journal of the Sociology of Language 47, 73-90.

SIES (Servei d'Investigació i Estudis Sociolingüístics). Electronic statistics. Retrieved October 12, 2009, from http:/www.edu.gva.es/polin/val/sies/ val_2006.htm 
Kokkuvõte. Raquel Casesnoves Fabra: Prestiiži mõju keele säilimisele: katalaani keel Valencias. Asjaolu, miks mingit keelt eelistatakse antud eluetapil teisele keelele, sõltub mitmetest erinevatest teguritest, nagu näiteks immigratsioon, kodus omandatud ja räägitav keel ning sellest, mis on dominant- ja ametlik keel. Olukordades, kus on võimalik keelte vahel valida, ei ole see valik siiski erapooletu, kuna väärtused, mis teatud keelele omistatakse mõjutavad valikut. Hispaania Valencia kogukonnas Hispaanias eksisteerib kõrvuti kaks riigikeelt: kogu Hispaania riigikeel - kastiilia keel - ja antud piirkonnale keeleajalooliselt iseloomulik keel - katalaani keel, mille taaselustamise protsess sai alguse 1980ndate alguses. Sel ajal oli katalaani keel teisejärgulise tähtsusega, seda seostati talurahva, maaelu ja madalamatest sotsiaalsetest klassidest pärinevate ebakultuursete inimestega. Meetodit, mis töötati välja hinnangute ja stereotüüpide selgitamiseks (nt peidetud maskide meetod, Ros 1984), kasutati taas 1990ndatel (Blas Arroyo 1995, Gomez Molina 1998) taaselustamisprogrammi efektiivsuse hindamiseks. Töö tulemustest selgus, et katalaani keele prestiiž kasvas üha enam ja enam, st et seda seostati üha enam kaasaegsete inimestega, linnaeluga, õppe- ja sotsiaalse edukusega. Selle põhjal eeldati (kuid ei tõestatud), et katalaani keele oluliselt paranenud maine peaks kajastuma selle kasutuses, mis peaks olema omakorda sagedasem ja laiemalt levinud. Uue aastatuhande alguses kasutati taas peidetud maskide meetodit, et hinnata katalaani keele tegelikku rääkimise prestiiži (Casesnoves ja Sankoff 2003). Kümme aastat hiljem korrati uurimust eesmärgiga vaadelda keelehoiakute arengut, samuti ka keele taaselustamise protsessi edukust. Käesolevas artiklis võrreldakse kahte andmebaasi, et hinnata keelehoiakute mõju katalaani keele kasutusele. Kas katalaani keele on nende aastate jooksul muutunud prestiižsemaks? Kui see on nii, siis kas sellel on mõju keelekasutusele, või vastupidi, kas on mingeid teisi faktoreid - nagu näiteks identiteet -, millel on olulisem osa katalaani keele rääkimisel?

Märksõnad: keelekontakt, keelehoiakud, keele taaselustamine, peidetud maskid, katalaani keel, Valencia, kastiilia keel 